\title{
Kebijakan Hukum Pidana Dalam Perlindungan Pekerja Rumah Tangga Korban Kekerasan
}

\author{
Siti Rahmawati \\ Pascasarjana Fakultas Hukum Universitas Islam Indonesia Yogyakarta Indonesia \\ Jln. Cik Di Tiro No. 1 Yogyakarta Indonesia \\ rwaty388@gmail.com
}

\begin{abstract}
In the employment sector, Domestic Workers (PRT, housemaids) are not categorized as formal occuparion. Therefore, domestic workers are included in the informal sector. These domestic workers in the informal sector are vulnerable to various acts of violence, hence are in dire need of extra protection from the state. This normative legal research concludes that the legal policies provided by the government in protecting domestic workers are in the form of providing restitution and compensation, counseling, medical services/assistance, legal assistance, and providing information. The policy is contained in Law Np. 23 of 2004 on the Elimination of Domestic Violence and Law No. 31 of 2014 on the Amendments to Law No. 13 of 2006 on the Protection of Witnesses and Victims. In addition, the role of government officials is very important for the implementation of legal protection for domestic workers. The role of the apparatus in providing protection to domestic workers victims of violence is regulated in the Law of the Republic of Indonesia No. 23 of 2004 concerning the Elimination of Domestic Violence.
\end{abstract}

Key Words: Domestic violence; domestic workers; legal policy

\begin{abstract}
Abstrak
Pada sektor ketenagakerjaan, eksistensi Pekerja Rumah Tangga (PRT) tidak masuk kategori pekerjaan formal. Oleh karena itu PRT dimasukkan ke dalam ruang lingkup informal. Sektor informal yang diisi oleh jenis kerja domestik seperti PRT rentan terhadap berbagai tindak kekerasan dan tentunya membutuhkan perlindungan ekstra dari negara. Penelitian hukum normatif ini berkesimpulan bahwa kebijakan hukum yang diberikan pemerintah dalam melindungi pekerja rumah tangga berupa pemberian restitusi dan kompensasi, konseling, pelayanan/bantuan medis, bantuan hukum, dan pemberian informasi. Kebijakan tersebut terdapat dalam Undang-Undang Nomor 23 Tahun 2004 tentang Penghapusan Kekerasan Dalam Rumah Tangga dan Undang-Undang Nomor 31 Tahun 2014 tentang Perubahan Atas Undang-Undang Nomor 13 Tahun 2006 tentang Perlindungan Saksi Dan Korban. Selain itu peran aparat pemerintah sangat penting untuk terselengaranya perlindungan hukum bagi Pekerja Rumah Tangga. Peran aparat dalam memberikan perlindungan kepada pekerja rumah tangga korban kekerasan diatur dalam Undang-Undang Republik Indonesia Nomor 23 Tahun 2004 tentang Penghapusan Kekerasan Dalam Rumah Tangga.
\end{abstract}

Kata-kata Kunci: Kebijakan hukum; KDRT; pekerja rumah tangga 


\section{Pendahuluan}

Kesibukan yang ada dalam keluarga karir membuat mereka tidak selalu bisa mengerjakan semua pekerjaan rumah tangga. Oleh karena itu, keluarga ini biasanya menghadirkan sosok pekerja rumah tangga (PRT) untuk membantu pekerjaan rumah sehari-hari. Pada sektor ketenagakerjaan, eksistensi PRT tidak dimasukkan kategori pekerjaan pada instansi-instansi pemerintah maupun swasta. Oleh karena itu, PRT dimasukkan ke dalam ruang lingkup informal. Sektor informal yang diisi oleh jenis kerja domestik seperti PRT rentan terhadap berbagai tindak kekerasan dan tentunya membutuhkan perlindungan ekstra dari negara. ${ }^{1}$

Kekerasan terhadap pekerja rumah tangga (PRT) merupakan salah satu bentuk kejahatan yang melecehkan dan menodai harkat kemanusiaan, serta patut dikategorikan sebagai jenis kejahatan melawan hukum kemanusiaan. ${ }^{2}$ Ironisnya, di Indonesia daftar korban PRT akibat kekerasan yang dilakukan oleh majikan masih terus berlangsung dari hari ke hari. Salah satu contoh kasus Mariyati (usia 15 tahun) di Tangerang yang mendapat perhatian dari berbagai lembaga karena kematiannya yang tragis dibunuh majikannya hanya karena dituduh mencuri roti dan bahkan dikubur di halaman rumahnya. Beruntung kejadian biadab tersebut diketahui sopir majikannya yang kemudian dilaporkan ke polisi. ${ }^{3}$

Di Indonesia kekerasan terhadap PRT sering kali terjadi. Dalam kurun waktu September 2016 kekerasan terhadap PRT mencapai 217 kasus. Kekerasan terhadap PRT meliputi kekerasan multijenis, meliputi baik kekerasan fisik maupun kekerasan ekonomi. Angka kekerasan multijenis mencapai 41 kasus. Kekerasan multijenis merupakan merupakan kekerasan psikis, fisik, ekonomi, hingga seksual yang diberikan terhadap PRT. Kekerasan fisik mencapai 102 kasus yang meliputi pemukulan, isolasi dan perdagangan manusia terhadap PRT. Sementara itu kekerasan ekonomi karena upah tidak dibayar mencapai 74 kasus. ${ }^{4}$

Adanya Undang-Undang No. 23 Tahun 2004 mengenai Penghapusan Kekerasan Dalam Rumah Tangga (UU PKDRT) dan UU No. 35 Tahun 2016 tentang Perlindungan Anak belum cukup mampu melindungi PRT dari kekerasan. Sedangkan dari aspek ketenagakerjaan, UU No. 13 Tahun 2003 tentang Ketenagakerjaan jo. UU No. 11 Tahun 2020 tentang Cipta Kerja (UU Ketenagakerjaan), belum mengakui PRT sebagai pekerja. Demikian pula, UU No.

1 Ana Sabhana Azmy, Negara dan Burub Migran Perempuan: Menelaab Kebijakan Perlindungan Masa Pemerintahan Susilo Bambang Yudhoyono 2004-2010, Yayasan Pustaka Obor Indonesia, Jakarta, 2012, hlm. 5.

${ }^{2}$ Alimuddin, Penyelesaian kasus KDRT di Pengadilan Agama, CV. Mandar Maju, Bandung, 2014, hlm. 38

3http://www.hukumonline.com/ kasus PRT. Diakses pada tanggal 20 Juli 2019, pukul 20.33 WIB.

${ }^{4}$ Kompas.com, Kamis, 15 September 2016, Hingga September 2016, Kekerasan Terbadap PRT Capai 217 Kasus, dalam http://nasional.kompas.com/ diakses 20 Juli 2019, pukul 20.33 WIB. 
40 Tahun 2004 tentang Jaminan Sosial (UU Jaminan Sosial) masih belum memasukkan PRT sebagai pekerja.

Hal di atas kemudian berakibat pada sebagian besar PRT mendapatkan upah di bawah upah minimum. Para PRT juga rentan menjadi korban berbagai pelanggaran dan kekerasan yang dilakukan oleh majikan atau orang di lingkungan keluarga. Situasi tersebut diperparah oleh fakta bahwa mayoritas PRT kurang memiliki akses atas pengetahuan, informasi dan layanan terkait hukum. Akibatnya, ketika menghadapi perselisihan atau kasus pelanggaran hak, mereka memilih untuk tidak melaporkan kasus mereka secara hukum atau mengambil tindakan hukum.

Penyebutan PRT sebagai pekerja sebenarnya sudah tercakup dalam pengertian buruh atau pekerja yang terdapat dalam peraturan perundangundangan. Undang-Undang Ketenagakerjaan mendefinisikan pekerja/buruh adalah setiap orang yang bekerja dengan menerima upah atau imbalan dalam bentuk lain (Pasal 1 angka 3). Berdasarkan pengertian tersebut nampak bahwa seharusnya PRT termasuk dalam pekerja sektor formal yang dilindungi oleh ketentuan undang-undang. Akan tetapi, pandangan tentang PRT bukan sebagai pekerja formal sudah tertanam dalam pandangan masyarakat. ${ }^{5}$ Di samping itu, tidak disebutnya secara langsung istilah PRT sebagai pekerja dalam ketentuan undang-undang telah memperkuat pandangan masyarakat dan selanjutnya dalam praktik PRT tetap tidak dimasukkan dalam lingkup hukum perburuhan.

Berdasarkan uraian di atas maka tergambar sejumlah permasalahan hukum terkait dengan pelindungan bagi PRT di Indonesia. Oleh karena itu, penulis tertarik untuk melakukan kajian hukum dengan judul "Kebijakan Hukum Pidana Dalam Perlindungan Pekerja Rumah Tangga Korban Kekerasan".

\section{Rumusan Masalah}

Adapun rumusan masalah dari penelitian ini adalah sebagai berikut: pertama, bagaimana kebijakan hukum dalam melindungi Pekerja Rumah Tangga yang menjadi Korban Kekerasan? Kedua, bagaimanakah peran aparat dalam memberikan pelindungan kepada Pekerja Rumah Tangga Korban Kekerasan?

\section{Tujuan Penelitian}

Penelitian ini bertujuan untuk: pertama, mengkaji kebijakan hukum dalam melindungi Pekerja Rumah Tangga yang menjadi korban kekerasan; Kedua, mengkaji peran aparat dalam memberikan pelindungan kepada Pekerja Rumah Tangga korban kekerasan.

5Tim LBH Apik, Kertas Posisi, Usulan Revisi Perda DKI Jakrta No 6 Tabun 1993 tentang Pramunisma, LBH Apik, Jakarta, 2002, hlm. 97 


\section{Metode Penelitian}

Penelitian ini merupakan penelitian hukum normatif. Penelitian ini menggunakan sumber data sekunder sebagai sumber data utama, ${ }^{6}$ yang dilengkapi dengan sumber data primer sebagai pendukung. Data sekunder terdiri dari bahan hukum primer dan sekunder. Bahan hukum primer terdiri atas Undang-Undang Dasar Negara Republik Indonesia Tahun 1945, serta peraturan perundang-undangan yang berkaitan dengan perlindungan hukum terhadap hak-hak perdata pekerja rumah tangga, seperti Undang-Undang Ketenagakerjaan, Undang-Undang Jaminan Sosial Ketenagakerjaan, Undangundang tentang Pengesahan ILO No. 182, Peraturan Pemerintah tentang Perlindungan Upah, Konvensi ILO No. 189, Permennaker No. 2 Tahun 2015 dan sebagainya. Bahan hukum sekunder adalah bahan hukum yang memberikan penjelasan mengenai bahan hukum primer, berupa hasil-hasil penelitian, karangan ilmiah dari kalangan hukum, danpenelitian-penelitian lain yang relevan dengan penelitian ini. Bahan hukum tersier adalah bahan yang memberikan petunjuk ataupun penjelasan terhadap bahan hukum primer dan bahan hukum sekunder, berupa kamus, ensiklopedia, majalah, surat kabar dan sebagainya yang dipergunakan untuk melengkapi ataupun menunjang data penelitian ini.

Peneliti mengumpulkan data yang diperlukan dengan cara library reseach yakni teknik pengumpulan bahan hukum melalui sumber kepustakaan. Selain itu, bahan hukum juga dapat diperoleh melalui dokumentasi. Sesuai dengan metode pendekatan yang digunakan yakni yuridis normatif maka strategi atau pendekatan yang digunakan dalam menganalisa data adalah metode analisis kualitatif.

\section{Hasil Penelitian dan Pembahasan}

\section{Kebijakan Hukum dalam Melindungi Pekerja Rumah Tangga Korban Kekerasan}

Indonesia sebagai negara hukum (rechtstaat) berimplikasi pada perlindungan terhadap Hak Asasi Manusia (HAM). Di dalam negara demokrasi, pengakuan dan perlindungan terhadap HAM merupakan salah satu ukuran tentang baik buruknya suatu pemerintahan. ${ }^{7}$

Kekerasan umumnya dikatakan mencakup serangan fisik saja. Namun kejahatan kekerasan menurut Yesmil Anwar dapat diartikan penggunaan kekuatan fisik dan kekuasaan, ancaman atau tindakan terhadap diri sendiri,

${ }^{6}$ Johny Ibrahim, Teori dan Metodologi Penelitian Hukum Normatif, Bayumedia, Surabaya, 2008, hlm. 268-269. hlm. 21.

7 Philipus M. Hadjon, Perlindungan Hukum bagi Rakyat Indonesia, Cet. I, PT. Bina Ilmu, Surabaya, 2007, 
perorangan atau sekelompok orang atau masyarakat yang mengakibatkan memar atau trauma, kematian, kerugian psikologis, kelainan perkembangan atau perampasan hak. ${ }^{8}$ Kekerasan sendiri memiliki 3 golongan, yaitu kekerasan fisik, kekerasan psikis dan kekerasan seksual.

Diskriminasi terhadap Pekerja Rumah Tangga dapat diartikan sebagai setiap pembedaan, pengucilan, atau pembatasan yang dibuat atas dasar jenis kelamin, yang bertujuan atau berpengaruh untuk menghalangi, meniadakan pengakuan terhadap dinikmatinya atau dilaksanakannya hak asasi manusia dan kebebasan dasar oleh kaum Pekerja Rumah Tangga. Pekerja Rumah Tangga dalam hal ini sering menjadi korban kekerasan baik itu korban dari suatu kejahatan yang dilakukan oleh penjahat maupun yang dilakukan oleh orang-orang terdekat seperti keluarga maupun dari keluarga dekat/kerabat dekat. ${ }^{9}$ Pekerja Rumah Tangga yang bekerja sebagai pekerja rumah tangga rentan mendapat kekerasan. Mereka sosok yang lemah, karena hanya sebagai pekerja yang ikut tuannya. Pentingnya korban mendapat pemulihan sebagai upaya penyeimbang kondisi korban yang mengalami gangguan, dikemukakan lebih luas oleh Muladi, bahwa korban kejahatan perlu dilindungi karena: ${ }^{10}$

Pertama, masyarakat dianggap sebagai suatu wujud sistem kepercayaan yang melembaga (system of institutionalized turst). Kepercayaan ini terpadu melalui norma norma yang diekspresikan di dalam struktur kelembagaan, seperti kepolisian, kejaksaan, pengadilan, dan sebagainya. Terjadinya kejahatan atas diri korban akan bermakna penghancuran sistem kepercayaan tersebut, sehingga pengaturan hukum pidana dan hukuman lain yang menyangkut korban sebagai sarana pengendalian sistem kepercayaan tadi. Kedua, adanya argumen kontrak sosial dan solidaritas sosial karena negara boleh dikatakan memonopoli seluruh reaksi sosial terhadap kejahatan dan melarang tindakantindakan yang bersifat pribadi. Karena itu, jika terdapat korban kejahatan, maka negara harus memperhatikan kebutuhan korban dengan cara peningkatan pelayanan dan pengaturan hak. Ketiga, Perlindungan korban yang biasanya dikaitkan dengan salah satu tujuan pemidanaan, yaitu penyelesaian konflik. Dengan penyelesaian konflik yang ditimbulkan oleh adanya tindak pidana akan memulihkan keseimbangan dan mendatangkan rasa damai dalam masyarakat.

Perlindungan hukum menurut Satijipto Raharjo adalah memberikan pengayoman terhadap Hak Asasi Manusia (HAM) yang dirugikan orang lain dan

\footnotetext{
8 Yesmil Anwar, Saat Menuai Kejahatan: Sebuah Pendeatan Sosiokultural Kriminologi Hukum, UNPAD Press: Bandung, 2004, hlm. 54.

9 Susi Delmiati, "Kebijakan Penegakan Hukum Terhadap Perempuan Korban Kekerasan Dalam Rumah Tangga”, Litigasi, Vol. 17(1), 2016, hlm. 3224.

${ }^{10}$ La Jamaa, "Perlindungan Korban Kekerasan Dalam Rumah Tangga Dalam Hukum Pidana Indonesia", Jurnal Cita Hukum, Vol. II No. 2 Desember 2014, hlm. 252.
} 
perlindungan itu di berikan kepada masyarakat agar dapat menikmati semua hak-hak yang diberikan oleh hukum. Hukum dapat difungsikan untuk mewujudkan perlindungan yang sifatnya tidak sekedar adaptif dan fleksibel, melainkan juga prediktif dan antisipatif. Hukum dibutuhkan untuk mereka yang lemah dan belum kuat secara sosial, ekonomi dan politik untuk memperoleh keadilan sosial. ${ }^{11}$

Mengacu pada penerapan perlindungan hak-hak korban kejahatan sebagai akibat dari terlanggarnya hak asasi yang bersangkutan, maka prinsip dasar dari perlindungan korban kejahatan dapat dilihat dari tiga teori, yakni: ${ }^{2}$ Pertama, teori utilitas. Teori ini menitikberatkan pada kemanfaatan yang terbesar bagi jumlah yang terbesar. Konsep pemberian perlindungan pada korban kejahatan dapat diterapkan sepanjang memberikan kemanfaatan yang lebih besar dibandingkan dengan tidak diterapkannya konsep tersebut, tidak saja bagi korban kejahatan, tetapi juga bagi sistem penegakan hukum pidana secara keseluruhan. Kedua, teori tanggung jawab. Menurut teori ini, bahwa pada hakekatnya subjek hukum (orang atau kelompok) bertanggung jawab terhadap segala perbuatan hukum yang dilakukannya, sehingga jika seseorang melakukan suatu tindak pidana yang mengakibatkan orang lain menderita kerugian (dalam arti luas), orang tersebut harus bertanggung jawab atas kerugian yang ditimbulkannya, kecuali ada alasan yang membebaskannya. Ketiga, teori ganti kerugian. Sebagai perwujudan tanggung jawab karena kesalahannya terhadap orang lain, pelaku tindak pidana dibebani kewajiban untuk memberikan ganti kerugian pada korban atau ahli warisnya.

Hak-hak korban berdasarkan dua undang-undang sama-sama harus dilindungi, indentitasnya dijamin kerahasiaanya oleh pemerintah. Pemerintah sebagai pengayom, dan pelindung harus dapat memenuhi hak-hak korban. Pemerintah harus benar-benar memfasilitasi korban agar korban lebih terbuka dengan kekerasan yang dialaminya. Tidak terkurung dalam ketakutan yang membuat mereka tidak berani untuk melaporkan tindak kekerasan yang telah dialami. Guna tegak atau berjalannya perlindungan hukum terhadap Pekerja Rumah Tangga korban kekerasan dalam rumah tangga diperlukan penegakan hukum yang jelas. Dalam penegakan hukum tersebut ada beberapa faktor yang mempengaruhinya. Menurut Soerjono Soekanto, dalam penegakan hukum akan dipengaruhi dari beberapa faktor: ${ }^{13}$

11 Satjipto Raharjo, Ilmu Hukum, PT. Citra Aditya Bakti, Bandung, 2000, hlm. 55.

12 La Jamaa, Op. Cit., hlm. 253. Siti Nurhayati, "Social Inclusion for Persons with Disabilities through Access to Employment in Indonesia", 2 (1) Prophetic Law Review 1, 2020, hlm. 3-6

13 Ibid., hlm. 323 
Pertama, Faktor Hukumnya Sendiri. Dalam praktik penyelenggaraan hukum di lapangan ada kalanya terjadi pertentangan antara kepastian hukum dan keadilan, hal ini disebabkan oleh konsepsi keadilan merupakan suatu rumusan yang bersifat abstrak, sedangkan kepastian hukum merupakan suatu prosedur yang telah ditentukan secara normatif. Justru itu, suatu kebijakan atau tindakan yang tidak sepenuhnya berdasar hukum merupakan sesuatu yang dapat dibenarkan sepanjang kebijakan atau tindakan itu tidak bertentangan dengan hukum. Maka pada hakikatnya penyelenggaraan hukum bukan hanya mencakup law enforcement saja, namun juga peace maintenance. Penyelenggaraan hukum sesungguhnya merupakan proses penyerasian antara nilai kaedah dan pola perilaku nyata yang bertujuan untuk mencapai kedamaian.

Kedua, faktor penegak hukum. Fungsi hukum, mentalitas atau kepribadian petugas penegak hukum memainkan peranan penting, kalau peraturan sudah baik, tetapi kualitas petugas kurang baik, ada masalah. Oleh karena itu, salah satu kunci keberhasilan dalam penegakan hukum adalah mentalitas atau kepribadian penegak hukum.

Ketiga, faktor sarana dan fasilitas. Faktor sarana atau fasilitas pendukung mencakup perangkat lunak dan perangkat keras, salah satu contoh perangkat lunak adalah pendidikan. Pendidikan yang diterima oleh Polisi dewasa ini cenderung pada hal-hal yang praktis konvensional, sehingga dalam banyak hal polisi mengalami hambatan di dalam tujuannya, diantaranya adalah pengetahuan tentang kejahatan komputer, dalam tindak pidana khusus yang selama ini masih diberikan wewenang kepada jaksa, hal tersebut karena secara teknis yuridis polisi dianggap belum mampu dan belum siap. Walaupun disadari pula bahwa tugas yang harus diemban oleh polisi begitu luas dan banyak.

Pemerintah telah membuat kebijakan untuk melindungi korban kekerasan dalam rumah tangga dalam Pasal 12 Undang-Undang Republik Indonesia Nomor 23 Tahun 2004 Tentang Penghapusan Kekerasan Dalam Rumah Tangga. Pasal 12 ayat (1) menyatakan Untuk melaksanakan ketentuan sebagaimana dimaksud dalam Pasal 11, Pemerintah merumuskan kebijakan tentang penghapusan kekerasan dalam rumah tangga, menyelenggarakan komunikasi, informasi, dan edukasi tentang kekerasan dalam rumah tangga, menyelenggarakan sosialisasi dan advokasi tentang kekerasan dalam rumah tangga dan menyelenggarakan pendidikan dan pelatihan sensitif gender dan isu kekerasan dalam rumah tangga serta menetapkan standar dan akreditasi pelayanan yang sensitif gender.

Kebijakan hukum yang dilakukan pemerintah untuk menekan kekerasan bagi pekerja rumah tangga dijelaskan dalam Pasal 15 yang berbunyi, "Setiap orang yang mendengar, melihat, atau mengetahui terjadinya kekerasan dalam rumah tangga wajib melakukan upaya-upaya sesuai dengan batas kemampuannya untuk mencegah berlangsungnya tindak pidana, memberikan 
perlindungan kepada korban, memberikan pertolongan darurat dan membantu proses pengajuan permohonan penetapan perlindungan.

Perlindungan yang diberikan berupa perlindungan secara fisik, agar korban tidak diganggu atau diancam secara fisik maupun psikisnya oleh pelaku. Perlindungan ini ditulis dalam Pasal 16 UU Penghapusan Kekerasan dalam Rumah Tangga yaitu dalam waktu $1 \times 24$ jam terhitung sejak mengetahui atau menerima laporan kekerasan dalam rumah tangga, kepolisian wajib segera memberikan perlindungan sementara pada korban. Perlindungan sementara sebagaimana dimaksud pada ayat (1) diberikan paling lama 7 hari sejak korban diterima atau ditangani. Dalam waktu 1 x 24 jam terhitung sejak pemberian perlindungan sebagaimana dimaksud pada ayat (1), kepolisian wajib meminta surat penetapan perintah perlindungan dari pengadilan.

Dalam penyelesaian perkara pidana, seringkali hukum terlalu mengedepankan hak-hak tersangka/terdakwa, sementara hak-hak korban diabaikan. Banyak ditemukan korban kejahatan kurang memperoleh perlindungan hukum yang memadai, baik perlindungan yang sifatnya immateriil maupun materiil. Korban kejahatan ditempatkan sebagai alat bukti yang memberi keterangan hanya sebagai saksi sehingga kemungkinan bagi korban untuk memperoleh keleluasaan dalam memperjuangkan haknya adalah kecil. Korban tidak diberikan kewenangan dan tidak terlibat secara aktif dalam proses penyidikan dan persidangan sehingga kehilangan kesempatan untuk memperjuangkan hak-hak dan memulihkan keadaannya akibat suatu kejahatan. ${ }^{14}$

Perlindungan hukum terhadap korban Kekerasan dalam Rumah Tangga selama ini didasarkan pada KUHP sebagai sumber hukum materil dan KUHAP sebagai hukum acaranya. Perlindungan hukum bagi korban seharusnya diatur secara eksplisit dalam KUHP. Misalnya dalam menjatuhkan pidana terhadap pelaku dipertimbangkan juga kerugian yang diderita oleh korban atau keluarga korban. Sehingga pelaku bisa saja di berikan pidana ganti rugi yang mungkin akan lebih bermanfaat bagi korban. Akses korban terhadap proses peradilan juga mesti diperhatikan. Korban berhak mengetahui perkembangan kasusnya. Apalagi apabila berkaitan dengan pelaku yang tidak mampu bertanggung jawab, maka korban juga dimungkinkan untuk mendapat kompensasi. ${ }^{15}$

Begitu pula apabila dilihat dalam KUHAP, pengaturan mengenai korban sama sekali termarjinalkan. KUHAP lebih banyak mengatur mengenai perlindungan terhadap tersangka, sedangkan perlindungan terhadap korban

${ }^{14}$ Rena Yulia, "Restorative Justice Sebagai Alternatif Perlindungan Hukum Terhadap Korban Kekerasan Dalam Rumah Tangga”, Jurnal Hukum dan Pembangunan Tabun ke-39 No. 2 April-Juni 2009, hlm. 249.

15 Ibid. 
tidak terumuskan secara lengkap. Hak yang diberikan KUHAP terhadap korban sangat terbatas. Diantaranya dapat ditemukan dalam Pasal 98-101 KUHAP. Dalam pasal ini diatur mengenai satu-satunya mekanisme ganti kerugian yang bisa dijalankan oleh korban yaitu melalui mekanisme Pasal 98 KUHAP yang disebut penggabungan perkara gugatan ganti kerugian. Tujuan dari penggabungan gugatan ganti kerugian ini adalah menyederhanakan proses perkara perdata yang timbul dari tindak pidana. Namun kerugian yang ditimbulkan hanya terbatas pada kerugian materiil saja, yaitu penggantian biaya yang telah dikeluarkan oleh korban, tidak mencakup pada penggantian kerugian immateril. Oleh karena itu pada prakteknya belum memenuhi kepentingan korban tindak pidana secara utuh. ${ }^{16}$

Secara teoritis, bentuk perlindungan terhadap korban kejahatan dapat diberikan dalam berbagai cara, tergantung pada penderitaan/kerugian yang diderita oleh korban. Ada beberapa bentuk perlindungan terhadap korban kejahatan yang lazim diberikan, antara lain. ${ }^{17}$ Pemberian Restitusi dan Kompensasi, Konseling, Pelayanan/Bantuan Medis, Bantuan Hukum dan Pemberian Informasi. Namun demikian, bentuk perlindungan tersebut terkadang tidak selalu didapatkan. Pada prakteknya hanya kerugian materiil saja yang bisa didapatkan, yaitu penggantian biaya yang telah dikeluarkan oleh korban namun tidak mencakup pada penggantian kerugian immaterial. Hal tersebut dikarenakan Kitab Undang-Undang Hukum Pidana dulunya banyak mengatur mengenai tersangka daripada korban.

Korban bisa mendapatkan haknya melalui restitusi dan kompensasi. Pengajuan restitusi sebenarnya dapat dilakukan mulai dari proses penyelidikan di kepolisian, hingga ke tingkat peradilan, namun masih banyak aparat penegak hukum yang tidak melakukannya. Sementara itu, korban dan keluarganya juga tidak mendapatkan informasi mengenai hal itu. Pelaksanaan pemenuhan hak restitusi bagi korban masih mengalami banyak hambatan, untuk itu perlu ada pembahasan mengenai model pemenuhan ganti kerugian yang dapat secara langsung dirasakan manfaatnya oleh korban dan keluarganya. ${ }^{18}$

Sebagai korban yang menderita secara fisik berhak untuk mendapatkan restitusi dan maupun kompensasi akibat penderitaan yang dialaminya. Hal ini tertuang dalam Deklarasi Prinsip-prinsip Kekuasaan (Resolusi Majelis Umum

16 Ibid.

17 Bambang Hartono, "Bentuk Perlindungan Hukum Terhadap Perempuan Pelapor Selaku Saksi Korban Kekerasan Dalam Rumah Tangga”, KEADILAN PROGRESIF Volume 5 Nomor 1 Maret 2014, hlm. 10-12.

18 Atikah Rahmi, "Pemenuhan Restitusi dan Kompensasi sebagai Bentuk Perlindungan Bagi Korban Kejahatan Seksual dalam Sistem Hukum di Indonesia", Delegate Jurnal Ilmu Hukum, Volume 4 Nomor 2, JuliDesember 2019, hlm. 144. 
PBB N0. 40/34, 29 November 1985) yang isinya mengatur. ${ }^{19}$ Para korban berhak untuk mendapatkan penggantian segala kerugian yang mereka derita. Mereka harus diinformasikan tentang hak-hak mereka untuk mendapatkan ganti rugi. Para pelaku atau pihak ketiga harus memberikan restitusi yang adil bagi para korban dan keluarga. Bilamana kompensasi tidak sepenuhnya didapatkan dari pelaku atas sumber-sumber lainnya negara harus berusaha menyediakan kompensasi keuangan. Para korban harus mendapat dukungan dan bantuan material, pengobatan, psikologis dan sosial yang diperlukan.

Ganti kerugian berupa restitusi dan kompensasi diharapkan dapat merasa dilindungi dan hak-hak nya terpenuhi. Ganti rugi atau restitusi yang dimaksudkan adalah ganti rugi atas hilangnya materi, penghasilan, penderitaan, biaya untuk tindakan perawatan medis dan/atau psikologis dan/atau kerugian lain yang diderita korban sebagai akibat tindakan kekerasan yang dialami korban. Selama ini banyak yang berpandangan bahwa hukuman pidana yang diterima tersangka kasus kekerasan merupakan hukuman setimpal bagi tersangka. Akan tetapi korban tidak mendapatkan ganti rugi secara immaterial selama korban berobat menyembuhkan luka-luka yang diderita, dan korban harus menanggung semua biaya pengobatan sendiri. Apabila ada korban yyang menuntut ganti rugi secara immaterial maka banyak yang berpandangan bahwa hal tersebut merupakan hal yang berlebihan.

Di dalam Peraturan Pemerintah Republik Indonesia Nomor 7 Tahun 2018 tentang Pemberian Kompensasi, Restitusi, dan Bantuan Kepada Saksi dan Korban permohonan kompensasi dapat diajukan oleh Korban, Keluarga, atau kuasanya. Pengajuan permohonan Kompensasi dapat dilakukan pada saat dilakukan penyelidikan pelanggaran hak asasi manusia yang berat atau sebelum dibacakan tuntutan oleh penuntut umum.

Pemerintah memberikan jaminan kepada korban berupa kompensasi yang telah disahkan kedalam peraturan perundang undangan agar korban benar-benar mendapatkan haknya. Selain kompensasi, korban juga mendapatkan restitusi. Restitusi dapat diajukan oleh korban, keluarga dan kuasa. Pemerintah memberikan perlinmdungan terhadap korban dengan mengundangkan Peraturan Peraturan Pemerintah Republik Indonesia Nomor 7 Tahun 2018 tentang Pemberian Kompensasi, Restitusi, Dan Bantuan Kepada Saksi Dan Korban. Peraturan pemerintah tersebut dengan jelas, menjelaskan mulai tahapan dan tata cara pengajuan. Diharapkan korban dapat mempergunakan peraturan pemerintah tersebut dengan bijak dan sebaik mungkin. 


\section{Peran Aparat dalam Memberikan Perlindungan Hukum kepada Pekerja Rumah Tangga Korban Kekerasan}

Pekerja rumah tangga rentan mendapat perlakuan diskriminatif, karena kesenjangan sosial yang didapatkan. Mereka dapat saja diperlakukan semenamena bahkan tidak dihargai. Perilaku diskriminasi yang ditujukan kepada pekerja rumah tangga dapat pula berupa pembatasan ekonomi terkait dengan upah ataupun jam kerja. Bahkan pembatasan lainnya seperti pelarangan bergaul, mengikuti organisasi juga terjadi.

Peran aparat penegak hukum dalam Undang-Undang No. 23 Tahun 2004 mengenai Penghapusan Kekerasan Dalam Rumah Tangga (PKDRT) merupakan sebuah terbosan hukum. Kepolisian, advokat, dan pengadilan dapat memberikan perlindungan dan pelayanan bagi korban kekerasan dalam rumah tangga terutama dengan diaturnya mekanisme perlindungan dari pengadilan bagi keamanan korban:20

\section{a. Peran Kepolisian}

Pada saat kepolisian menerima laporan kekerasan dalam rumah tangga, mereka harus segera menjelaskan kepada korban mereka mendapatkan pelayanan dan pendampingan. Kepolisian memperkenalkan identitas mereka dengan menjelaskan bahwa kekerasan dalam rumah tangga sudah merupakan kewajiban dari kepolisian untuk melindungi korban. Ini diatur dalam Pasal 16 sampai dengan 20, 26, 27, 35, dan 36. Setelah menerima laporan tersebut, langkah-langkah yang harus diambil kepolisian yaitu memberikan perlindungan sementara kepada korban, meminta surat penetapan perintah perlindungan dari pengadilan dan melakukan penyelidikan

b. Peran Advokat

Advokat dalam memberikan perlindungan dan pelayanan wajib memberikan konsultasi hukum mengenai hak-hak korban dan proses peradilan. Mendampingi korban pada penyidikan dan pemeriksaan di dalam sidang, serta melakukan koordinasi dengan sesame penegak hukum, relawan pendamping dan pekerja sosial agar proses peradilan berjalan sebagaimana mestinya.

c. Peran Pengadilan

Pengadilan harus mengeluarkan surat penetapan perintah perlindungan bagi korban anggota keluarga lain yang diajukan oleh kepolisian. Pengadilan dapat mempertimbangkan permohonan korban atau kuasanya untuk menetapkan kondisi khusus berupa pembatasan gerak pelaku, larangan memasuki tempat tinggal bersama, larangan membuntuti, mengawasi atau mengintimidasi korban. Korban dapat melaporkan kepada polisi jika terjadi pelanggaran perintah perlindungan, kemudian

20 Kasmanita, "Perlindungan Hukum Terhadap Korban Kekerasan Dalam Rumah Tangga (KDRT)", Jurisprudentie, Volume 6 Nomor 2 Desember 2019, hlm. 245. 
menyusun laporan bersama kepada pengadilan, yang wajib memanggil pelaku untuk mengadakan penyelidikan dan meminta pelaku membuat pernyataan tertulis yang isinya kesanggupan untuk mematuhi perintah perlindungan yang dikeluarkan oleh pihak pengadilan dan menerima sanksi yang telah ditetapkan jika masih saja melanggar.

Aparat penegak hukum seperti polisi menjadi garda terdepan bagi korban untuk melindungi korban kekerasan. Peran aparat kepolisian berdasarkan UU KDRT sebagai berikut ini:21

1. Konsultasi hukum, yang mana korban diberi hak untuk sharring/ konsultasi atas peristiwa hukum yang terjadi pada diri korban dengan advokat yang kemudian advokat dapat menarik kesimpulan atas peristiwa hukum tersebut lalu memberikan solusi yang tepat untuk korban;

2. Melakukan mediasi ataupun negoisasi diantara para pihak korban dan pelaku PKDRT, dalam proses ini advokat menjadi pihak yang netral diantara pihak korban dan pelaku serta member masukan/nasehat untuk menemukan pemecahan masalah atas peristiwa hokum yang terjadi;

3. Mendampingi korban pada tingkat penyidikan, penuntutan, pemeriksaan, dalam sidang pengadilan, advokat pada proses ini diharuskan melakukan pendampingan dan pemantauan atas setiap tahapan proses hukum karena setiap perkembangan kasus harus dikawal dengan ketat. Hal ini sangat penting dan mempengaruhi alat bukti serta penjatuhan pidana terhadap pelaku. Yang dikhawatirkan ketika tidak ada pendampingan si korban yang mungkin tidak stabil emosinya karena kejadian hukum yang menimpa dirinya dan rasa ketakutan apabila memberikan kesaksian yang sebenarnya, si korban akan di intimidasi oleh pelaku sehingga si korban dalam kesaksiannya berbeli-belit maka dapat meringankan pelaku dalam penjatuhan pidana;

4. Advokat dalam hal pendampingan terhadap korban pada tingkat penyidikan, penuntutan, pemeriksaan, dalam sidang pengadilan harus melalui koordinasi dengan sesama penegak hukum, relawan pendamping dan pekerja social supaya informasi yang didapat lebih akurat.

Aparat sebagai penegak hukum memiliki peran yang penting. Penegakan hukum sebagai bagian dari perlindungan hukum. Dalam prosesnya, penegakan hukum dipengaruhi oleh lima faktor yaitu ${ }^{22}$ pertama, faktor hukum atau norma atau peraturan perundang-undangan, terlepas norma tersebut telah mengakomodir atau kurang berperspektif terhadap kelompok rentan. Kedua, faktor aparat penegak hukum, yakni penegak hukum dan pemerintah yang berwenang dalam penegakan hukumnya. Penegak hukum tidak terlepas dari pola pikir, komitmen, psikologi dan

21 Mahmudin Kobandaha, "Perlindungan Hukum Terhadap Anak Korban Kekerasan Dalam Rumah Tangga Dalam Sistem Hukum Di Indonesia”, Jurnal Hukum Unsrat, Vol. 23 No. 8 Januari 2017, hlm. 88-89.

${ }^{22}$ Wiwik Afifah, Op. Cit., hlm. 66 
pengaruh sosial dalam penegakannya. Ketiga, faktor sarana pendukung penegakan hukum, yakni segala ketersedian sarana dan prasarana untuk penegakan hukum preventif maupun represif. Keempat, faktor masyarakat, yaitu kesadaran dan kepatuhan hukum yang merefleksi perilaku masyarakat, psikologi masyrakat dalam keterlibatannya membuat dan menjalankan norma. Kelima, faktor kebudayaan, yaitu hasil karya, cipta, dan rasa yang di dasarkan pada karsa manusia di dalam pergaulan hidup yang diterima dan diyakini oleh masyarakat untuk dilaksanakan sebagai perilaku publik.

Tangung jawab aparat terhadap korban kekerasan terdapat beberapa faktor yang mempengaruhi kinerja dari aparat kepolisian. Kinerja dari aparat juga membutuhkan dukungan dari masyarakat. Apabila melihat tindak kekerasan, sebaiknya masyarakat segera memberikan perlindungan dan membawa korban ke kantor polisi terdekat untuk mendapatkan perlindungan dari pihak kepolisian.

Tanggung jawab aparat juga ditunjukkan dalam Undang-Undang Pasal 182 mengenai penyidikan.

(1)Selain penyidik pejabat Polisi Negara Republik Indonesia, juga kepada pegawai pengawas ketenagakerjaan dapat diberi wewenang khusus sebagai penyidik pegawai negeri sipil sesuai dengan peraturan perundang-undangan yang berlaku.

(2) Penyidik Pegawai Negeri Sipil sebagaimana dimaksud dalam ayat (1) berwenang melakukan pemeriksaan atas kebenaran laporan serta keterangan tentang tindak pidana di bidang ketenagakerjaan, melakukan pemeriksaan terhadap orang yang diduga melakukan tindak pidana dibidang ketenagakerjaan, meminta keterangan dan bahan bukti dari orang atau badan hukum sehubungan dengan tindak pidana di bidang ketenagakerjaan, melakukan pemeriksaan atau penyitaan bahan atau barang bukti dalam perkara tindak pidana di bidang ketenagakerjaan, melakukan pemeriksaan atas surat dan/atau dokumen lain tentang tindak pidana dibidang ketenagakerjaan, meminta bantuan tenaga ahli dalam rangka pelaksanaan tugas penyidikan tindak pidana di bidang ketenagakerjaan, menghentikan penyidikan apabila tidak terdapat cukup bukti yang membuktikan tentang adanya tindak pidana di bidang ketenagakerjaan.

Tanggung jawab aparat kepolisian dalam UU PKDRT diatur dalam Pasal 16 sampai dengan Pasal 20, 26, 27, 35 dan 36. Dalam Pasal 16-20 membahas mengenai perlindungan kepada korban kekerasan, polisi wajib memberikan perlindungan kepada korban kekerasan agar korban merasa tenang dan terlindungi. Dalam Pasal 17 dijelaskan bahwa perlindingan dapat bekerja sama dengan beberapa tenaga pendukung. Pasal 17 berbunyi “Dalam memberikan perlindungan sementara, kepolisian dapat bekerja sama dengan tenaga kesehatan, pekerja sosial, relawan pendamping, dan/atau pembimbing rohani untuk 
mendampingi korban." Korban secara langsung selain mendapat perlindungan, korban juga mendapatkan perawatan dari tenaga medis bahkan mendapatkan bimbingan rohani untuk psikisnya. Polisi juga wajib memberitahu hak-hak korban untuk mendapat pelayanan dan pendampingan. Polisi juga wajib segera melakukan penyelididkan setelah mendapatkan laporan dari korban.

Kepolisian segera menyampaikan kepada korban tentang identitas petugas untuk pengenalan kepada korban, kekerasan dalam rumah tangga adalah kejahatan terhadap martabat kemanusiaan dan kewajiban kepolisian untuk melindungi korban.

Polisi wajib menjelaskan kepada korban identitas petugas kepada korban, menjelaskan mengenai kekerasan merupakan kejahatran dan korban wajib melaporkan apabila melihat ataupun mengalami kekerasan. Pelaporan tindak kekerasan ini dapat dikuasakan oleh kelaurga ataupun kuasa hukum korban. Tanggung jawab polisi dalam melindungi korban kekerasan lainnya yaitu dengan menangkap pelaku dengan bukti yang cukup. Termaktub dalam Pasal 36 ayat (1) “Untuk memberikan perlindungan kepada korban, kepolisian dapat menangkap pelaku dengan bukti permulaan yang cukup karena telah melanggar perintah perlindungan."

Aparat lainnya yang memiliki tanggung jawab melindungi korban kekerasan yaitu kejaksaaan. Peran Kejaksaan diatur Pasal 10 huruf (a) yang berbunyi "perlindungan dari pihak keluarga, kepolisian, kejaksaan, pengadilan, advokat, lembaga sosial, atau pihak lainnya baik sementara maupun berdasarkan penetapan perintah perlindungan dari pengadilan.

Advokat juga memiliki tanggung jawab melindungi korban kekerasan, termaktub dalam Pasal 25 Huruf (a), (b) dan (c). Dalam hal memberikan perlindungan dan pelayanan, advokat wajib memberikan konsultasi hukum yang mencakup informasi mengenai hak-hak korban dan proses peradilan; mendampingi korban di tingkat penyidikan, penuntutan, dan pemeriksaan dalam sidang pengadilan dan membantu korban untuk secara lengkap memaparkan kekerasan dalam rumah tangga yang dialaminya. Mendampingi korban di tingkat penyidikan, penuntutan, dan pemeriksaan dalam sidang pengadilan dan membantu korban untuk secara lengkap memaparkan kekerasan dalam rumah tangga yang dialaminya. Melakukan koordinasi dengan sesama penegak hukum, relawan pendamping, dan pekerja sosial agar proses peradilan berjalan sebagaimana mestinya.

Advokat merupakan salah satu aparat hukum yang berperan memberikan konsultasi hukum kepada korban terkaot hak-hak korban, advokat juga mendampingi korban selama proses peradilan (di tingkat penyidikan, 
penuntutan, dan pemeriksaan dalam sidang pengadilan) berlangsung mempertahankan hak-hak korban yang seharusnya didapatkan oleh korban.

Aparat lainnya yang bertanggung jawab untuk memberikan perlindungan korban kekerasan pekerja rumah tangga yaitu pengadilan. Pengadilan sangat berperan memperjuangkan hak-hak korban sehingga korban merasa dilindungi secara hukum oleh pengadilan. Peran pengadilan diatur Pasal 28 sampai dengan Pasal 34, Pasal 37 dan Pasal 38. Pasal 28 berbunyi "Ketua pengadilan dalam tenggang waktu 7 hari sejak diterimanya permohonan wajib mengeluarkan surat penetapan yang berisi perintah perlindungan bagi korban dan anggota keluarga lain, kecuali ada alasan yang patut." Pasal tersebut menyatakan bahwa pengadilan wajib memberikan kepada korban dan keluarga korban apabila telah ada permohonan perlindungan yang masuk ke pengadilan. Surat permohonan perlindungan dapat diajukan oleh korban atau keluarga korban, teman korban, kepolisian, relawan pendamping atau pembimbing rohani.

Surat permohonan perlindungan yang diajukan selain korban maka harus mendapat persetujuan korban, akan tetapi apabila terdapat keadaan tertentu maka dapat diajukan tanpa persetujuan korban. Surat permohonan perlindungan dapat diajukan secara tertulis maupun secara lisan. Apabila permohonan diajukan secara lisan maka panitera wajib mencatat surat permohonan perlindungan tersebut.

Perintah perlindungan yang diberikan oleh pengadilan selama 1 tahun, dan dapat diperpanjang dengan cara melakukan perpanjangan minimal 7 hari sebelum masa berlaku perlindungan habis. Perintah perlindungan dapat diperpanjang dengan ketetapan dari pengadilan. Akan tetapi perintah perlindungan hanya dapat diperpanjang selam 1 kali. Perpanjangan perintah perlindungan tentunya dengan pertimbangan keterangan dari korban, tenaga kesehatan, pekerja sosial, relawan pendamping, dan/atau pembimbing rohani.

Tapi dalam Pasal 34 perintah perlindungan dapat diperpanjang 1 atau lebih dengan berdasarkan pertimbangan bahaya yang mungkin timbul. Tentunya tambahan perintah perlindungan tersebut berdasarkan pertimbangan keterangan dari mempertimbangkan keterangan dari korban, tenaga kesehatan, pekerja sosial, relawan pendamping, dan/atau pembimbing rohani.

Pasal 37 juga masih mengenai perat pengadilan dalam melindungi korban kekerasan pekerja rumah tangga, pertama Korban, kepolisian atau relawan pendamping dapat mengajukan laporan secara tertulis tentang adanya dugaan pelanggaran terhadap perintah perlindungan. Kedua, dalam hal pengadilan mendapatkan laporan tertulis sebagaimana dimaksud pada ayat (1), pelaku diperintahkan menghadap dalam waktu $3 \times 24$ jam guna dilakukan pemeriksaan. 
Ketiga, pemeriksaan sebagaimana dimaksud pada ayat (2) dilakukan oleh pengadilan di tempat pelaku pernah tinggal bersama korban pada waktu pelanggaran diduga terjadi.

Beberapa aparat seperti kepolisian, advokat dan pengadilan memiliki peran bertanggung jawab melindungi korban kekerasan yang telah diatur oleh undangundang. Oleh karena itu peran tersebut harus dilaksanakan dan diwujudkan dengan sebaik mungkin, agar tidak ada perbedaan strata antara pekerja maupun majikan, walaupun majikan seorang pelaku, hukum harus tetap ditegakkan.

Peran aparat sudah sangat jelas dan harapannya tentu dapat dijalankan dengan baik tanpa membeda-bedakan strata sosial, karena Indonesia merupakan negara hukum yang tentunya semua yang dilakukan harus berdasarkan hukum yang berlaku. Selain mendapatkan perlindungan, korban juga mendapatkan hak pemulihan yang tentunya telah diatur dalam UU PKDRT.

\section{Penutup}

Kebijakan hukum yang diberikan pemerintah dalam melindungi pekerja rumah tangga berupa pemberian restitusi dan kompensasi, konseling, pelayanan/bantuan medis, bantuan hukum, dan pemberian informasi. Kebijakan tersebut terdapat dalam Undang-Undang Republik Indonesia Nomor 23 Tahun 2004 tentang Penghapusan Kekerasan Dalam Rumah Tangga dan UndangUndang Republik Indonesia Nomor 31 Tahun 2014 tentang Perubahan Atas Undang-Undang Nomor 13 Tahun 2006 tentang Perlindungan Saksi dan Korban.

Peran aparat dalam memberikan perlindungan kepada pekerja rumah tangga korban kekerasan diatur dalam Undang-Undang Republik Indonesia Nomor 23 Tahun 2004 tentang Penghapusan Kekerasan Dalam Rumah Tangga. Aparat penegak hukum, yaitu kepolisian, kejaksaan, advokat dan pengadilan, dalam memberikan perlindungan terhadap korban kekerasan dalam rumah tangga dapat bekerjasama dengan tenaga kesehatan, pekerja sosial, relawan, pendamping dan pembimbing rohani.

Guna membantu penanganan Pekerja Rumah Tangga korban kekerasan dalam rumah tangga, maka perlu diadakan shelter-shelter yang diadakan oleh lembaga-lembaga yang concern terhadap persoalan-persoalan tindak kekerasan. Peran serta aktif masyarakat dalam merespon dan melaporkan kasus kekerasan dalam rumah tangga dilingkungannya kepada kepolisian. Dibentuknya UndangUndang (selain Undang-Undang Republik Indonesia Nomor 23 Tahun 2004 tentang Penghapusan Kekerasan Dalam Rumah Tangga) yang secara detail mengatur bentuk perlindungannya dari berbagai permasalahn PRT baik hubungan kerja, diskriminasi, kekerasan, upah, dan lainya yang secara eksplisit 
menunjukkan adanya perlindungan pada PRT sebagai bagian dari anggota keluarga. Agar mampu membendung banyaknya diskriminasi, kekerasan, hubungan kerja tidak setara pada PRT.

\section{Daftar Pustaka}

\section{Buku}

Alimuddin, Penyelesaian Kasus KDRT (Kekerasan Dalam Rumah Tangga) di Pengadilan Agama, CV. Mandar Maju, Bandung, 2014.

Anwar, Yesmil, Saat Menuai Kejahatan: Sebuah Pendeatan Sosiokultural Kriminologi Hukum, UNPAD Press, Bandung, 2004.

Azmy, Ana Sabhana, Negara dan Buruh Migran Perempuan: Menelaah Kebijakan Perlindungan Masa Pemerintahan Bambang Yudhoyono 2004-2010, Yayasan Pustaka Obor Indonesia, Jakarta, 2012.

Hadjon, Philipus M., Perlindungan Hukum bagi Rakyat Indonesia, PT. Bina Ilmu, Surabaya, 2007.

Ibrahim, Johny, Teori \& Metodologi Penelitian Hukum Normatif, Bayumedia, Surabaya, 2008.

Raharjo, Satjipto, Ilmu Hukum, PT. Citra Aditya Bakti, Bandung, 2000.

\section{Jurnal}

Delmiati, Susi, "Kebijakan Penegakan Hukum Terhadap Perempuan Korban Kekerasan Dalam Rumah Tangga", Litigasi, Vol. 17, No. (1), 2016.

Hartono, Bambang, "Bentuk Perlindungan Hukum Terhadap Perempuan Pelapor Selaku Saksi Korban Kekerasan Dalam Rumah Tangga", Lurnal Keadilan Progresif, Volume 5, Nomor 1, Maret 2014.

Jamaa, La, "Perlindungan Korban Kekerasan Dalam Rumah Tangga Dalam Hukum Pidana Indonesia", Jurnal Cita Hukum, Vol. II, No. 2, Desember 2014.

Kasmanita, "Perlindungan Hukum Terhadap Korban Kekerasan Dalam Rumah Tangga (KDRT)", Jurisprudentie, Volume 6, Nomor 2, Desember 2019.

Kobandaha, Mahmudin, "Perlindungan Hukum Terhadap Anak Korban Kekerasan Dalam Rumah Tangga Dalam Sistem Hukum Di Indonesia", Jurnal Hukum Unsrat, Vol. 23, No. 8, Januari 2017.

Nurhayati, Siti, "Social Inclusion for Persons with Disabilities through Access to Employment in Indonesia", 2 (1) Prophetic Law Review 1, 2020.

Rahmi, Atikah, "Pemenuhan Restitusi Dan Kompensasi Sebagai Bentuk Perlindungan Bagi Korban Kejahatan Seksual dalam Sistem Hukum di Indonesia", Delegate Jurnal Ilmu Hukum, Volume 4, Nomor 2, JuliDesember 2019.

Yulia, Rena, "Restorative Justice Sebagai Alternatif Perlindungan Hukum Terhadap Korban Kekerasan dalam Rumah Tangga", Jurnal Hukum dan Pembangunan, No. 2, April-Juni, 2009. 


\section{Media Elektronik}

Apik, LBH, "Kertas Posisi Usulan Revisi Perda DKI Jakarta No. 6 Tahun 1993 tentang Pramuwisma", diakses pada http:/ /www.Apiknet@centrin.net.id

Hukumonline, "Kasus Mariyati: Wujud Minimnya Perlindungan Hukum terhadap PRT", diakses pada https://www.hukumonline.com/berita/baca/ hol9496/kasus-mariyati-wujud-minimnya-perlindungan-hukumterhadap-prt?page $=2$ /

Kompas.com, "Hingga September 2016, Kekerasan terhadap PRT Capai 217 Kasus", diakses pada https://nasional.kompas.com/read/2016/09/15/ 16403781/hingga.

september.2016.kekerasan.terhadap.prt.capai.217.kasus? page=all

\section{Peraturan Perundang-Undangan}

Kitab Undang-undang Hukum Acara Pidana

Undang-Undang Nomor 23 Tahun 2004 tentang Penghapusan Kekerasan dalam Rumah Tangga

Undang-Undang Nomor 31 Tahun 2014 tentang Perubahan Atas Undang-Undang Nomor 13 Tahun 2006 tentang Perlindungan Saksi Dan Korban

Peraturan Pemerintah Nomor 7 Tahun 2018 tentang Pemberian Kompensasi, Restitusi, dan Bantuan kepada Saksi dan Korban 